\title{
Comprehensive study for Anammox process via multistage anaerobic baffled reactors
}

\author{
Sherif Ismail ${ }^{1, *}$, and Ahmed Tawfik \\ ${ }^{1}$ Egypt-Japan University of Science and Technology (E-JUST); Environmental Engineering \\ Department, P.O. Box 179 - New Borg El Arab City - Postal Code 21934, Alexandria, Egypt
}

\begin{abstract}
Continuous anaerobic ammonia oxidation (Anammox) process in multistage anaerobic baffled (MABR) reactor was investigated. The reactor was operated for approximately 150 days at constant hydraulic retention time (HRT) of $48 \mathrm{~h}$ and was fed with synthetic wastewater containing nitrite and ammonium as main substrates. The MABR was inoculated with mixed culture bacteria collected from activated sludge plant (41.6 g MLSS/L and 19.1 g MLVSS/L). The MABR reactor exhibited excellent performance for the start-up of Anammox process within a period of 35 days. The start-up period was divided into four successive phases; cell lysis, lag, activity elevation and steady state. Total inorganic nitrogen (TIN) removal efficiency of $96.8 \pm 0.9 \%$ was achieved at steady state conditions, corresponding to nitrogen removal rate (NRR) of $50.2 \pm 1.7 \mathrm{mg} \mathrm{N} / \mathrm{L} \cdot \mathrm{d}$. Moreover, the effect of HRT on the Anammox process was assessed with applying five different HRTs of (48, 38.4, 28.8, 19.2 and 9.6 h). Decreasing HRT from 48 to $9.6 \mathrm{~h}$ reduced the removal efficiencies of $\mathrm{NH}_{4}-\mathrm{N}, \mathrm{NO}_{2}-\mathrm{N}$ and TIN from $97.7 \pm 2.2$ to $49.0 \pm 9.8 \%$, from $95.7 \pm 1.9$ to $71.0 \pm 8.5 \%$ and from $96.8 \pm 0.9$ to $57.9 \pm 9.1 \%$, respectively, that corresponding to reduction in NRR from $50.8 \pm 1.2 \mathrm{mg} \mathrm{N} / \mathrm{L} \cdot \mathrm{d}$ at HRT of $48 \mathrm{~h}$ to $32.5 \pm 5.0 \mathrm{mg} \mathrm{N} / \mathrm{L} \cdot \mathrm{d}$ at HRT of $9.6 \mathrm{~h}$.
\end{abstract}

\section{Introduction}

Several types of wastewater such as wastewater from fertilizer industry, dewatering of digested sludge and landfill leachate have high concentrations of ammonium and low concentrations of biodegradable organic compounds (low $\mathrm{C} / \mathrm{N}$ ratio). Nitrogen compounds presented in such a wastewater create a significant adverse environmental impact on the receiving water bodies because of their role in eutrophication, consumption of oxygen content of receiving waters, and their toxicity to aquatic species, including human beings [1]. Conventionally, the removal of nitrogen (ammonium) is accomplished by the combination of nitrification and denitrification processes [2]. Both of these processes are energy consuming and are associated with high costs. Moreover, these processes have an additional environmental impact due to high biomass production and greenhouse gas $\left(\mathrm{CO}_{2}, \mathrm{~N}_{2} \mathrm{O}\right.$, etc.) emission, which promote global warming $[3,4]$.

\footnotetext{
*Corresponding author: sherif.ismail@ejust.edu.eg,ahmed.tawfik@ejust.edu.eg
} 
Anaerobic ammonium oxidation which was initially discovered in a denitrifying fluidized bed reactor in 1995 [5], has been reported as a novel and promising biotechnology for the treatment of ammonium-rich wastewater especially with low $\mathrm{C} / \mathrm{N}$ ratio. Under anaerobic or anoxic conditions, Anammox bacteria, which belong to the order Planctomycetales, accomplish autotrophic ammonium $\left(\mathrm{NH}_{4}^{+}\right)$oxidation to produce dinitrogen $\left(\mathrm{N}_{2}\right)$ gas while using nitrite $\left(\mathrm{NO}_{2}^{-}\right)$as an electron acceptor and $\mathrm{CO}_{2}$ as carbon source, producing scanty amounts of nitrate $\left(\mathrm{NO}_{3}{ }^{-}\right)$(Eq. (1)) [6,7]. This process offers several advantages over conventional nitrification-denitrification systems including higher nitrogen removal rate, lower operational cost and less space requirement [4]. The application of the Anammox process in wastewater treatment results in significant reduction in energy $(60 \%)$ and greenhouse gas emission (90\%) compared to those of traditional biological nitrogen removal processes $[8,9]$.

$$
\begin{aligned}
\mathrm{NH}_{4}{ }^{+}+1.32 \mathrm{NO}_{2}{ }^{-}+0.066 \mathrm{HCO}_{3}{ }^{-}+ & 0.13 \mathrm{H}^{+} \rightarrow 1.02 \mathrm{~N}_{2}+0.256 \mathrm{NO}_{3}{ }^{-}+0.066 \mathrm{CH}_{2} \mathrm{O}_{0.5} \mathrm{~N}_{0.15} \\
& +2.03 \mathrm{H}_{2} \mathrm{O}
\end{aligned}
$$

Many studies have been carried out to investigate the effectiveness of Anammox process in various configurations, and these studies have achieved distinct reactor performances such as up-flow anaerobic sludge blanket (UASB) $[10,11]$, sequencing batch reactor (SBR) [12, 13], membrane bioreactor [14, 15] and anaerobic baffled reactor (ABR) [16, 17]. However, the ABR reactor is known as a highly efficient anaerobic reactor configuration compared with other anaerobic systems. The ABR system has several advantages such as longer retention times, less vulnerable to check loadings, the ability to separate the anaerobic metabolic phases in addition to its simple design since no special gas separation, no packing material, no moving parts and no mechanical mixing are required [18]. The anaerobic baffled reactor (ABR) has been described as a series of up-flow anaerobic sludge blanket (UASBs), which does not need granulation for its operation. Therefore, it has lower start-up period than the other high rate reactors [19]. A typical ABR consists of a series of vertical baffles that the liquid flows alternately upward and downward between the partitions, and on its upward passage the waste flows through an anaerobic sludge blanket.

The Anammox process treating ammonia rich wastewater was investigated insufficiently using anaerobic baffled reactor. Therefore, the main objective of this study is to investigate the effectiveness of multistage anaerobic baffled reactor (MABR) configuration on the startup of Anammox bacterial community, assess the potential of using MABR for continuous Anammox process, and study the effect of hydraulic retention time (HRT) on nitrogen removal efficiencies.

\section{Materials and methods}

\subsection{Experimental set-up of multistage anaerobic baffled reactor (MABR) and operating condition}

A multistage anaerobic baffled (MABR) reactor fabricated from Perspex was designed and used for the experimental study. Fig. 1 shows a schematic diagram of the lab-scale multistage anaerobic baffled reactor (MABR) used in this investigation. The working volume of the Anammox MABR reactor was $20 \mathrm{~L}$, and the total dimensions of the reactor were $77.5 \mathrm{~cm}$ in length, $12.5 \mathrm{~cm}$ in width, and $33 \mathrm{~cm}$ in height. The MABR system consists of five sequential compartments ended with settler for excess sludge removal. The reactor compartments were separated by vertical standing where inside each compartment, downcomer and riser regions were constructed using a slanted edge $\left(45^{\circ}\right)$ vertical baffle to direct the flow evenly through the riser and to increase the contact time between the substrate and bacterial community. The 
downcomer to riser volume ratio amounted to 1:3. Each compartment was equipped with three sampling ports to withdraw the wastewater and sludge samples. The working dimensions for each compartments were $12.5 \times 12.5 \times 25 \mathrm{~cm}$. Black cloth was used to cover the reactor preventing light penetration in order to inhibit the growth of photosynthetic bacteria [20]. The produced gas was collected via porthole on the top of the reactor as shown in Fig. 1.

Synthetic wastewater was continuously fed from the tank into the reactor using a peristaltic pump (Masterflex - USA, Cole-Parmer Instrument Company) to control the flow rate of influent feeding. The reactor was operated at constant flow rate of $10 \mathrm{~L} / \mathrm{d}$ and HRT of $48 \mathrm{~h}$ at ambient temperature $\left(24 \pm 6^{\circ} \mathrm{C}\right)$. The influent concentrations of ammonia and nitrite were maintained both at $50 \mathrm{mg} \mathrm{N} / \mathrm{L}$ in order to keep the nitrite concentration at nontoxic level with an average nitrogen loading rate (NLR) of $52.2 \pm 3.74 \mathrm{mg} \mathrm{N} / \mathrm{L} \cdot \mathrm{d}$. The $\mathrm{pH}$ of the influent was adjusted to be $7.5 \pm 0.3$ with $1 \mathrm{M}$ HCL. Anaerobic condition in the feeding tank was maintained by flushing the influent synthetic wastewater with argon gas before feeding to the reactor [11]. Throughout the operation, no sludge was intentionally removed from the reactor.

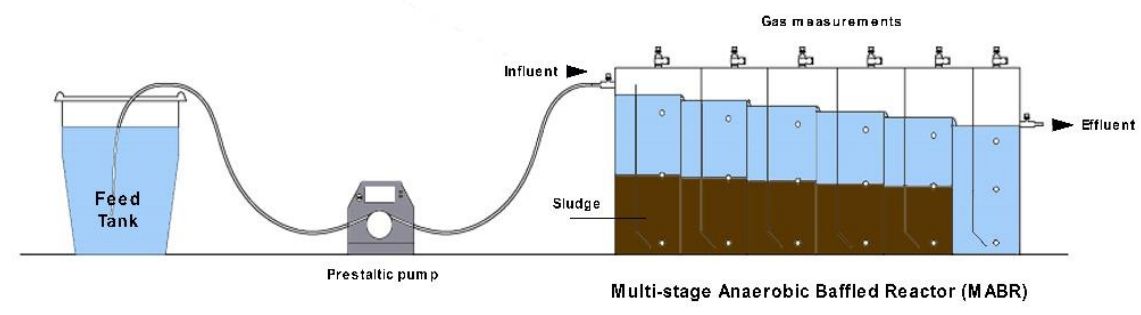

Fig. 1. Schematic diagram of the experimental MABR reactor.

\subsection{Synthetic wastewater and inoculation}

A synthetic ammonia rich wastewater was used for the continuous experiments. Ammonium and nitrite was supplemented to mineral medium in the form of $\left(\mathrm{NH}_{4}\right)_{2} \mathrm{SO}_{4}$ and $\mathrm{NaNO}_{2}$, respectively and was added as required. The composition of the mineral medium was $\mathrm{KH}_{2} \mathrm{PO}_{4}(27.2 \mathrm{mg} / \mathrm{L}), \mathrm{CaCl}_{2} \cdot 2 \mathrm{H}_{2} \mathrm{O}(180 \mathrm{mg} / \mathrm{L}), \mathrm{MgSO}_{4} \cdot 7 \mathrm{H}_{2} \mathrm{O}(300 \mathrm{mg} / \mathrm{L})$ and $\mathrm{KHCO}_{3}$ $(500 \mathrm{mg} / \mathrm{L})$. The trace elements were supplied at a dosage of $1 \mathrm{~mL}$ per $\mathrm{L}$ of wastewater of trace elements solution 1 and 2. Trace elements solution 1 contained (per $1 \mathrm{~L}$ distilled water) $\mathrm{FeSO}_{4}(5 \mathrm{~g})$, EDTA ( $\left.5 \mathrm{~g}\right)$; and trace elements solution 2 contained (per $1 \mathrm{~L}$ distilled water) EDTA (15 g), $\mathrm{MnCl}_{2} \cdot 4 \mathrm{H} 2 \mathrm{O}(0.99 \mathrm{~g}), \mathrm{CuSO}_{4} \cdot 5 \mathrm{H}_{2} \mathrm{O}(250 \mathrm{mg}), \mathrm{ZnSO}_{4} \cdot 7 \mathrm{H}_{2} \mathrm{O}$ (430 mg), $\mathrm{NiCl}_{2} \cdot 6 \mathrm{H}_{2} \mathrm{O}(190 \mathrm{mg}), \mathrm{CoCl}_{2} \cdot 6 \mathrm{H}_{2} \mathrm{O}(240 \mathrm{mg}), \mathrm{H}_{3} \mathrm{BO}_{4}(14 \mathrm{mg}), \mathrm{NaSeO}_{4} \cdot 10 \mathrm{H}_{2} \mathrm{O}(210 \mathrm{mg})$, $\mathrm{NaMoO}_{4} \cdot 2 \mathrm{H}_{2} \mathrm{O}(220 \mathrm{mg})$ and $\mathrm{NaWO}_{4} \cdot 2 \mathrm{H}_{2} \mathrm{O}(50 \mathrm{mg})$ [21].

The ABR reactor was seeded with mixed culture bacteria obtained from the thickener of activated sludge treatment plant located in Alexandria, Egypt. The collected seeding sludge was further concentrated in gravitational settling tank for $24 \mathrm{~h}$. Afterwards, the concentrated sludge was filtered through sieve No. 10 to remove coarse suspended solids, and then this concentrated sludge was used for inoculation. The concentration of mixed liquor suspended solids (MLSS) and mixed liquor volatile suspended solids (MLVSS) of the seed sludge were 41.6 and $19.1 \mathrm{~g} / \mathrm{L}$, respectively. The reactor was initially inoculated with $10 \mathrm{~L}$ sludge $(50 \%$ of working volume) resulting in inoculum to substrate ratio of $5.2 \mathrm{mg} \mathrm{N} / \mathrm{g} \mathrm{VS}$. 


\subsection{Analytical methods}

Samples from the influent and the treated effluent were collected three times a week for analysis of ammonium nitrogen $\left(\mathrm{NH}_{4}-\mathrm{N}\right)$, nitrite nitrogen $\left(\mathrm{NO}_{2}-\mathrm{N}\right)$, nitrate nitrogen $\left(\mathrm{NO}_{3}-\mathrm{N}\right)$, $\mathrm{pH}$ and oxidation reduction potential (ORP). All analyses were carried out according to the standard methods for examination of water and wastewater [22]. In addition, physical and chemical parameters were also analyzed for each compartment of the reactor at each operational condition's steady state. All measurements were performed in triplicates and average values were presented. Analysis of liquid samples was recorded (mean \pm standard deviation) during steady state operation. Nitrogen removal rate was calculated as the sum of ammonium and nitrite consumption.

\section{Results and discussion}

\subsection{The start-up of Anammox bacteria in MABR reactor (days 1-150)}

The lab scale multistage anaerobic baffled reactor MABR was used to study the treatment of ammonia rich wastewater by Anammox process. The reactor was operated at constant hydraulic retention time HRT of 2 days. The influent ammonia and nitrite was adjusted to be $50 \mathrm{mg} / \mathrm{L}$ each, corresponding to total nitrogen loading rate of $50 \mathrm{mg} \mathrm{N} / \mathrm{L} \cdot \mathrm{d}$. The occurrence of the Anammox activity was demonstrated through a simultaneous depletion of nitrite $\mathrm{NO}_{2}-\mathrm{N}$ and ammonia $\mathrm{NH}_{4}-\mathrm{N}$ coupled to a small production of nitrate $\mathrm{NO}_{3}-\mathrm{N}$. The data presented in Fig. 2, 3 and 4 revealed that the start-up period was divided into four distinct phases based on the amount of ammonia removed: cell lysis phase (1-7 days), lag phase (8-23 days), propagation or activity elevation phase (24-35 days) and stationary phase (after 35 days).

At the beginning of the Anammox MABR start-up, the concentration of $\mathrm{NH}_{4}-\mathrm{N}$ was increased. Accordingly, the ammonium removal efficiency was below zero. The results in Fig. 2 shows that the ammonia concentration was increased from $59.6 \mathrm{mg} / \mathrm{L}$ to $99.3 \mathrm{mg} / \mathrm{L}$ with ammonium removal of $-66.6 \%$ in the beginning as shown in Fig 3 . This phase named cell lysis phase as $\mathrm{NH}_{4}-\mathrm{N}$ and organic matter were released from denitrifying bacteria autolysis due to the initial adverse conditions of the reactor [23]. The $\mathrm{NO}_{2}-\mathrm{N}$ was completely consumed in this phase (Figs. 2 and 3). This removal could be attributed to the prevalence of denitrification process. The organic released from cell lysis can be used as an electron donor by heterotrophic denitrifying bacterial communities for denitrification process [24]. The sludge lysis phase lasted for only one week.

Lag phase lasted for 15 days (days 8-23). In this phase, the average effluent ammonium concentration and the average ammonium removal efficiency were $38.6 \pm 3.4 \mathrm{mg} / \mathrm{L}$ and $21.9 \pm 5.9 \%$, respectively. The average ammonium removal rate was $5.4 \pm 1.5 \mathrm{mg} / \mathrm{L} \cdot \mathrm{d}$, suggesting a juvenile Anammox activity in MABR reactor. Similarly, the high nitrite removal efficiency and small amount of nitrate production confirmed denitrification as well as cell lysis still continued in this phase (Fig. 2). Moreover, the effluent $\mathrm{NO}_{3}-\mathrm{N}$ concentration of increased progressively. The effluent $\mathrm{NO}_{3}-\mathrm{N}$ concentration of $4.3 \mathrm{mg} / \mathrm{L}$ was achieved in day 23, which revealed itself to start a slight Anammox activity (Fig. 2).

In activity elevation phase, continuous increase in ammonia and nitrite removal was observed. Figs. 2 and 3 shows that, during activity elevation phase, a significant increase in ammonia removal efficiency was monitored. The ammonia removal efficiency increased from $19.5 \%$ on day 23 to $94.9 \%$ on day 35 . The ammonium removal rate (ARR) and total nitrogen removal rate (NRR) were increased from 4.74 to $21.28 \mathrm{mg} \mathrm{N} / \mathrm{L} \cdot \mathrm{d}$ and from 29.85 to $45.55 \mathrm{mg} \mathrm{N} / \mathrm{L} \cdot \mathrm{d}$, respectively, which suggested that Anammox performance progressively enhanced in this phase. Nitrite concentration in the effluent were still the same as mentioned 
in the cell lysis and lag phase (Fig. 2). $\mathrm{NO}_{3}-\mathrm{N}$ concentration started to increase during activity elevation phase. The average nitrate concentration of $8.4 \pm 1.2 \mathrm{mg} / \mathrm{L}$ was achieved in the effluent of the reactor. At the end of this stage, the nitrite removal to ammonium conversion molar ratio was 1.14 . Whereas, nitrate production to ammonium removal ratio was 0.17 , which were nearly to the theoretical stoichiometric ratio of 1.32 and 0.26 through the Anammox process [25]. The MABR was successfully started-up on day 35 .

During the stationary phase (steady state), ammonium removal was continuously monitored (days 36-150). The influent concentrations of $\mathrm{NH}_{4}-\mathrm{N}$ and $\mathrm{NO}_{2}-\mathrm{N}$ were maintained $50 \mathrm{mg} / \mathrm{L}$. Nitrogen removal efficiency of the system was relatively stable. Ammonium, nitrite and total nitrogen removal efficiencies were $97.7 \pm 2.9 \%, 94.6 \pm 3.3 \%$ and $96.2 \pm 2.2 \%$ at HRT of 2 days and NLR of $52.2 \pm 3.7 \mathrm{mg} / \mathrm{L} \cdot \mathrm{d}$, respectively corresponding to NRR of $50.2 \pm 3.9 \mathrm{mg} \mathrm{N} / \mathrm{L} \cdot \mathrm{d}$. The average effluent $\mathrm{NH}_{4}-\mathrm{N}$ and $\mathrm{NO}_{2}-\mathrm{N}$ were $1.2 \pm 1.6$ and $2.8 \pm 1.6 \mathrm{mg} / \mathrm{L}$, respectively. The production of $\mathrm{NO}_{3}-\mathrm{N}$ increased stepwise, and the maximum $\mathrm{NO}_{3}-\mathrm{N}$ concentration in the effluent was $21.4 \mathrm{mg} / \mathrm{L}$ on day 120 . The $\mathrm{NH}_{4}-\mathrm{N}, \mathrm{NO}_{2}-\mathrm{N}$ and $\mathrm{NO}_{3}-\mathrm{N}$ stoichiometric ratio was $1: 1: 0.21$, i.e. nearly the same as the theoretical ratio of $1: 1.32: 0.26$. These results indicated that the Anammox reactor had reached a steady state.

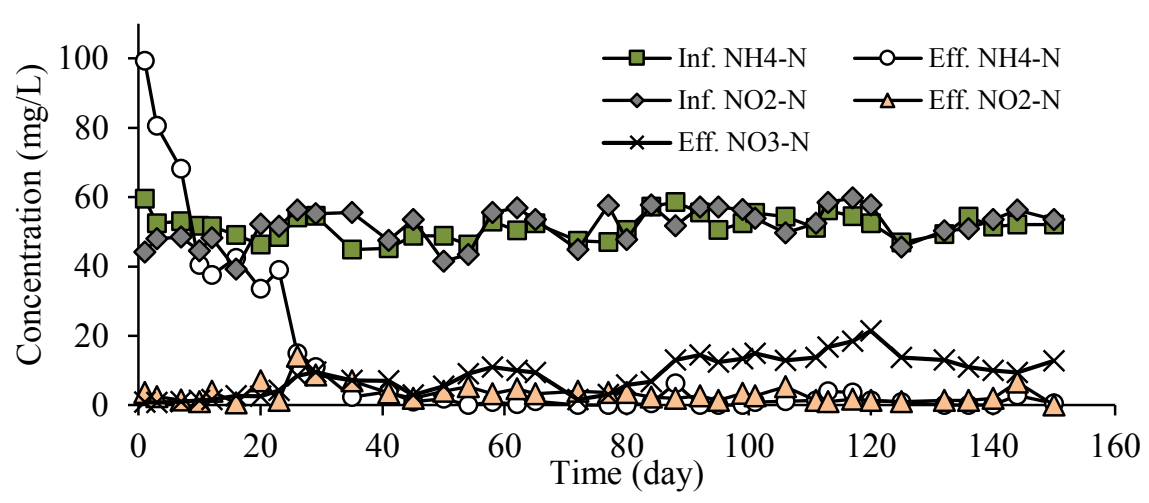

Fig. 2. Time course of nitrogen compounds in influent and effluent in the MABR reactor.

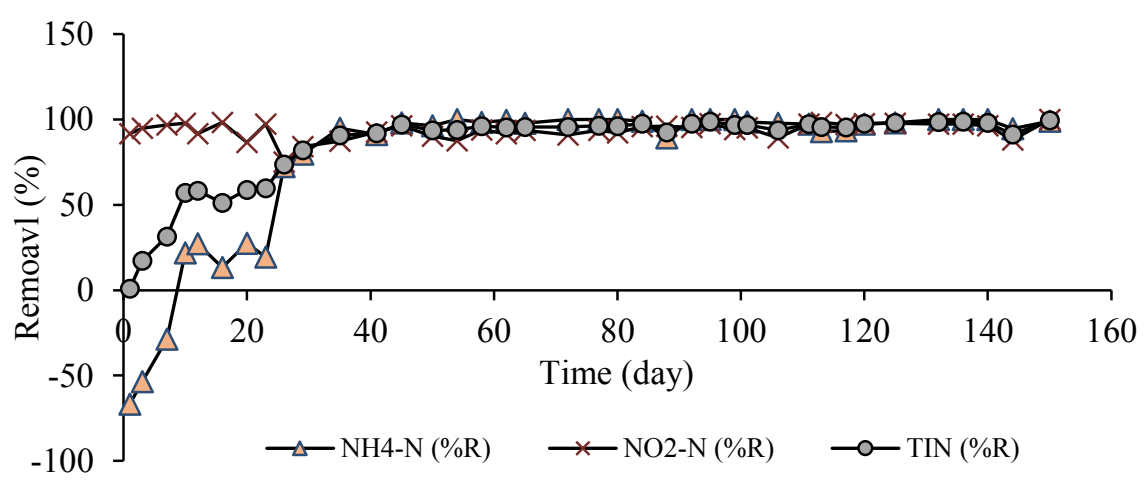

Fig. 3. Time course of nitrogen compounds removal efficiencies in the MABR reactor. 


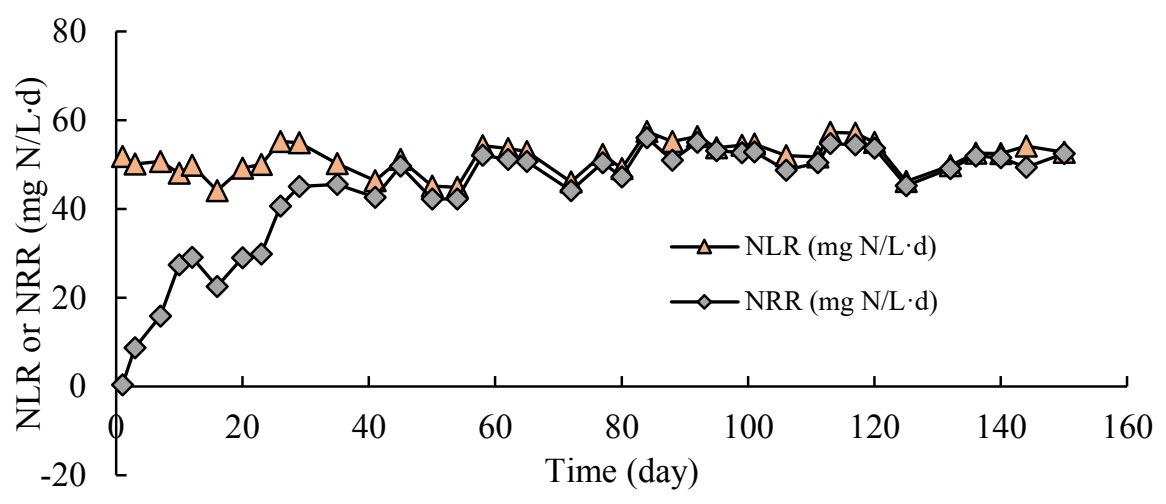

Fig. 4. Time course of NLR and NRR in the MABR reactor.

Based on the above results, the MABR reactor exhibited excellent performance for the start-up of Anammox process within a period of 35 days using activated sludge (mixed culture bacteria, 41.6 g MLSS/L and 19.1 g MLVSS/L) as inoculum. Tang, Zheng, et al. [24] demonstrated that an Anammox reactor was successfully started up on day 73. Tsushima et al. observed Anammox reactions after a 55-day the start-up process [26].

\subsection{Behavior of Anammox process in the MABR reactor at different HRTs}

Throughout the reactor's operation, the influent ammonium and nitrite concentrations were maintained constant whereby the nitrogen loading rate (NLR) was progressively increased by shortening HRT. The nitrogen removal efficiencies in MABR reactor is depicted in Table 1. Five different HRTs $(48,38.4,28.8,19.2$ and 9.6) were applied in order to investigate the effect of HRT on Anammox process performance, which accompanied by changing NLR. The results obtained revealed that decreasing the HRT from 48 to $9.6 \mathrm{~h}$ reduced the removal efficiencies of $\mathrm{NH}_{4}-\mathrm{N}, \mathrm{NO}_{2}-\mathrm{N}$ and $\mathrm{TIN}$ from $97.7 \pm 2.2$ to $49.0 \pm 9.8 \%$, from $95.7 \pm 1.9$ to $71.0 \pm 8.5 \%$ and from $96.8 \pm 0.9$ to $57.9 \pm 9.1 \%$, respectively, that corresponding to decrease in NRR from $50.8 \pm 1.2 \mathrm{mg} \mathrm{N} / \mathrm{L} \cdot \mathrm{d}$ at HRT of $48 \mathrm{~h}$ to $32.5 \pm 5.0 \mathrm{mg} \mathrm{N} / \mathrm{L} \cdot \mathrm{d}$ at HRT of $9.6 \mathrm{~h}$. Short HRT probably reduced the substrate utilization efficiency as the contact time between the microorganisms and substrate was insufficient resulting in high residual values of Nitrogen ammonia. The residual values of $\mathrm{NH}_{4}-\mathrm{N}$ and $\mathrm{NO}_{2}-\mathrm{N}$ were increased from $1.2 \pm 1.1$ and $2.1 \pm 1.1 \mathrm{mg} / \mathrm{L}$ to $26.0 \pm 7.1$ and $13.8 \pm 8.4 \mathrm{mg} / \mathrm{L}$ while decreasing the HRT from 48 to $9.6 \mathrm{~h}$. these observation is in agreement with Tang et al. [6] who mentioned the same behaviour in up-flow anaerobic sludge bed (UASB) reactor were initially inoculated with anaerobic granular sludge taken from a paper mill wastewater treatment plant.

Table 1. Performance of Anammox process in MABR at different HRTs.

\begin{tabular}{|c|c|c|c|c|c|}
\hline \multirow{2}{*}{ Parameters } & \multicolumn{5}{|c|}{ HRTs (h) } \\
\cline { 2 - 6 } & $\mathbf{4 8}$ & $\mathbf{3 8 . 4}$ & $\mathbf{2 8 . 8}$ & $\mathbf{1 9 . 2}$ & $\mathbf{9 . 6}$ \\
\hline Eff. $\mathrm{NH}_{4}-\mathrm{N}(\mathrm{mg} / \mathrm{L})$ & $1.2 \pm 1.1$ & $5.2 \pm 3.9$ & $11.1 \pm 5.1$ & $18.1 \pm 6.4$ & $26.0 \pm 7.1$ \\
\hline Eff. $\mathrm{NO}_{2}-\mathrm{N}(\mathrm{mg} / \mathrm{L})$ & $2.1 \pm 1.1$ & $3.4 \pm 1.4$ & $4.0 \pm 1.4$ & $5.9 \pm 1.5$ & $13.8 \pm 8.4$ \\
\hline $\mathrm{DO}(\mathrm{mg} / \mathrm{L})$ & $0.02 \pm 0.03$ & $0.03 \pm 0.04$ & $0.05 \pm 0.03$ & $0.1 \pm 0.2$ & $0.26 \pm 0.04$ \\
\hline $\mathrm{NH}_{4}-\mathrm{N}$ removal (\%) & $97.7 \pm 2.2$ & $89.5 \pm 8.4$ & $78.0 \pm 10.5$ & $64.4 \pm 12.8$ & $49.0 \pm 9.8$ \\
\hline $\mathrm{NO}_{2}-\mathrm{N}$ removal (\%) & $95.7 \pm 1.9$ & $93.0 \pm 2.2$ & $91.6 \pm 2.0$ & $82.2 \pm 2.4$ & $71.0 \pm 8.5$ \\
\hline TN removal (\%) & $96.8 \pm 0.9$ & $91.0 \pm 4.1$ & $84.2 \pm 4.3$ & $75.0 \pm 5.3$ & $57.9 \pm 9.1$ \\
\hline NRR (mg N/L·d) & $50.8 \pm 1.2$ & $48.1 \pm 1.1$ & $44.8 \pm 1.0$ & $40.4 \pm 3.4$ & $32.5 \pm 5.0$ \\
\hline
\end{tabular}




\section{Conclusion}

In this study, Anammox process can be readily started up from conventional activated sludge in MABR reactor within 35 days. The cultivation process can be divided into four phases; cell lysis, lag, activity elevation and steady state. The ammonia concentration was increased from $54.9 \pm 3.9 \mathrm{mg} / \mathrm{L}$ (influent) to $82.6 \pm 15.6 \mathrm{mg} / \mathrm{L}$ in the effluent during cell lysis phase. Anammox activity in lag phase, amounted to $21.9 \pm 5.9 \%$. The major portion of Anammox performance was occurred in activity elevation phase, where the nitrogen removal was increased from $19.5 \%$ to $94.9 \%$. Anammox reaction process was nearly completed in the stationary phase which strongly indicated that the reactors were attained steady state conditions where the reactors were operated at nitrogen loading rates (NLRs) ranging from 44.1 to $57.5 \mathrm{mg} \mathrm{N} / \mathrm{L} \cdot \mathrm{d}$. The performance of Anammox process was relatively stable. Ammonium, nitrite and total nitrogen removal efficiencies were $97.7 \pm 2.9 \%, 94.6 \pm 3.3 \%$ and $96.2 \pm 2.2 \%$ at HRT of 2 days and NLR of $52.2 \pm 3.7 \mathrm{mg} / \mathrm{L} \cdot \mathrm{d}$, respectively corresponding to $\mathrm{NRR}$ of $50.2 \pm 3.9 \mathrm{mg} \mathrm{N} / \mathrm{L} \cdot \mathrm{d}$. The average effluent $\mathrm{NH}_{4}-\mathrm{N}$ and $\mathrm{NO}_{2}-\mathrm{N}$ were $1.2 \pm 1.6$ and $2.8 \pm 1.6 \mathrm{mg} / \mathrm{L}$, respectively. Furthermore, the results obtained indicated the negative effect of decreasing the HRT in the performance of MABR reactor. The $\mathrm{NH}_{4}-\mathrm{N}, \mathrm{NO}_{2}-\mathrm{N}$ removal efficiencies were reduced to $49.0 \pm 9.8 \%$ and $71.0 \pm 8.5 \%$ respectively at HRT of $9.6 \mathrm{~h}$.

The first author is grateful for the Egyptian ministry of higher education which granted him a full PhD scholarship and for Egypt Japan University (EJUST) and Japan International Cooperation Agency (JICA) for providing all the facilities to accomplish in this work.

\section{References}

1. D. Paredes, P. Kuschk, T.S.A. Mbwette, F. Stange, R.A. Muller, H. Koser, Eng. Life Sci. 7, 13-25 (2007)

2. S. Tomar, S.K. Gupta, Appl. Microbiol. Biotechnol. 99, 9245-9254 (2015)

3. A. Daverey, S.H. Su, Y.T. Huang, S.S. Chen, S. Sung, J.G. Lin, Water Res. 47, 2929-2937 (2013)

4. M.S.M. Jetten, M. Wagner, J. Fuerst, M. Van Loosdrecht, G. Kuenen, M. Strous, Curr. Opin. Biotechnol. 12, 283-288 (2001)

5. A. Mulder, A.A. van de Graaf, L.A. Robertson, J.G. Kuenen, FEMS Microbiol. Ecol. 16, 177-183 (1995)

6. C.J. Tang, P. Zheng, C.H. Wang, Q. Mahmood, J.Q. Zhang, X.G. Chen, L. Zhang, J.W. Chen, Water Res. 45, 135-144 (2011)

7. L.F. Ren, S.Q. Ni, C. Liu, S. Liang, B. Zhang, Q. Kong, N. Guo, Environ. Sci. Pollut. Res. 22, 2925-2934 (2015)

8. Y. Ren, N. Yan, Q. Wen, Z. Fan, T. Wei, M. Zhang, J. Ma, Chem. Eng. J. 175, 1-7 (2011)

9. S.Q. Ni, J.Y. Ni, D.L. Hu, S. Sung, Bioresour. Technol. 110, 701-705 (2012)

10. B. Ma, Y. Peng, S. Zhang, J. Wang, Y. Gan, J. Chang, S. Wang, S. Wang, G. Zhu, Bioresour. Technol. 129, 606-611 (2013)

11. C.J. Tang, P. Zheng, L.Y. Chai, X.B. Min, Int. Biodeterior. Biodegrad. 82, 141-148 (2013)

12. Y. Tao, D.W. Gao, Y. Fu, W.M. Wu, N.Q. Ren, Bioresour. Technol. 104, 73-80 (2012)

13. N. Chamchoi, S. Nitisoravut, Chemosphere 66, 2225-2232 (2007)

14. D. Akgul, C.K. Aktan, K. Yapsakli, B. Mertoglu, Biodegradation 24, 399-412 (2013) 
15. T. Wang, H. Zhang, D. Gao, F. Yang, G. Zhang, Bioresour. Technol. 122, 78-82 (2012)

16. J.J. Yu, H. Chen, Q. Guo, Z.Z. Zhang, L.X. Guo, R.C. Jin, Ecol. Eng. 83, 19-27 (2015)

17. C. Chen, F. Sun, H. Zhang, J. Wang, Y. Shen, X. Liang, Bioresour. Technol. 216, 571-578 (2016)

18. H. Chen, Q.Q. Chen, Z.J. Shi, J.J. Xu, A.N. Liu, L.L. He, Y.H. Wu, M.L. Shi, R.C. Jin, Ecol. Eng. 92, 229-235 (2016)

19. A. Elreedy, A. Tawfik, Energy Procedia 74, 1071-1078 (2015)

20. H. Li, S. Zhou, W. Ma, G. Huang, B. Xu, Desalination 286, 436-441 (2012)

21. A.A. van de Graaf, P. de Bruijn, L.A. Robertson, M.S.M. Jetten, J.G. Kuenen, Microbiology 142, 2187-2196 (1996)

22. APHA, 25th ed., Am. Public Heal. Assoc. Water Environ. Fed, Washington DC, USA, 1995

23. J. Guo, S. Wang, J. Lian, H. Hao, W. Guo, Y. Liu, Y. Song, Bioresour. Technol. 220, 641-646 (2016)

24. C.J. Tang, P. Zheng, Q. Mahmood, J.W. Chen, J. Ind. Microbiol. Biotechnol. 36, 1093-1100 (2009)

25. M. Strous, M. Jetten, Appl. Environ. Microbiol. 63, 2446-2448 (1997)

26. I. Tsushima, Y. Ogasawara, T. Kindaichi, H. Satoh, S. Okabe, 41, 1623-1634 (2007) 